\title{
ГЕОГРАФИЯ
}

\section{Особенности влияния рельефа Витебска на климатические параметры}

\author{
А.Б. Торбенко ${ }^{\circledR}$, А.Н. Галкин ${ }^{1}$, Д. В. Новиков ${ }^{1}$, И.Н. Иванова-Логвинова ${ }^{2}$ \\ ${ }^{1}$ Витебский государственный университет имени П. М. Мамерова, Республика Беларусь \\ (210038, г. Витебск, Московский просп., 33) \\ ${ }^{2}$ Витебский областной цеентр по гидрометеорологии и мониторингу окружающей среды, \\ Республика Беларусь \\ (210101, г. Витебск, просп. Фрунзе, 81)
}

\begin{abstract}
Аннотация: Цель: рассмотреть особенности мезоклиматических условий территории Витебска, оценить роль рельефа в его формировании.

Maтериальl u методbl: для достижения поставленной цели построена базовая векторная карта и цифровая модель рельефа территории города, проведена оценка основных климатообразующих факторов (экспозиция и крутизна склонов, формы мезорельефа, тип застройки, наличие или отсутствие водотоков и водоемов, массивов древесно-кустарниковой растительности).

Результаты и обсуждение: выполнен геотопологический анализ городской территории, выделены типы местоположений, в пределах которых особенности рельефа обусловливают особый температурный и ветровой режим, формируют четкие отличия климатических параметров по сравнению с окрестными территориями. Создана базовая карта местоположений поверхностей рельефа города для вычисления мезоклиматических отклонений в их пределах и на ее основе построена схематическая карта мезоклиматических условий Витебска; дана характеристика этим условиям.

Заключение: исходя из сопряженного анализа рельефа и метеорологических условий для города, установлено семь вариантов мезоклимата. При этом четыре из них представлены весьма ограниченно. На большей части территории Витебска, занятой выровненными возвышенными поверхностями, наблюдаются условия близкие к зональным (за пределами города) с отклонениями, обусловленными влиянием «острова тепла». Особые мезоклиматические условия формируются в котловинах и крупных долинах, что проявляется в снижении скоростей ветра, более плавном ходе средних и увеличении экстремальных значений температур.
\end{abstract}

Ключевые слова: рельеф, экспозиция склонов, крутизна склонов, геоинформационная система, цифровая модель рельефа, мезоклиматические условия.

Для цитирования: Торбенко А.Б., Галкин А.Н., Новиков Д. В., Иванова-Логвинова И.Н. Особенности влияния рельефа Витебска на климатические параметры // Вестник Воронежского государственного университета. Серия: География. Геоэкология, 2021, № 3, с. 13-24, DOI: https://doi.org/10.17308/geo.2021.3/3596.

\section{ВВЕДЕНИЕ}

Рельеф, являющийся климатообразующим фактором, влияет на распределение основных метеорологических показателей - температуру воздуха, количество осадков, направление ветра. Масштабы влияния могут быть разными - от глобальных и региональных (крупные горные системы или обширные равнинные территории) до местных (речные долины, небольшие возвышенности). Осо- бый случай - климатические условия городов, где кроме естественных особенностей рельефа свой вклад в распределение метеопараметров вносят искусственные неоднородности поверхности, сформированные разновысотной застройкой, направлением улиц, зданий и сооружений. Кроме того, контролируемые рельефом микро- и мезоклиматические параметры в свою очередь, в значительной степени, формируют картину загрязнения город-

(C) Торбенко А.Б., Галкин А.Н., Новиков Д. В., Иванова-Логвинова И.Н., 2021

$凶$ Торбенко Андрей Борисович, e-mail: torbenko_a@mail.ru

(c) (i) Контент доступен под лицензией Creative Commons Attribution 4.0 License. 
ской среды и, в частности, атмосферного воздуха. Таким образом, влияние рельефа на климатические характеристики и качество атмосферного воздуха - важная часть эколого-геоморфологической характеристики городской территории.

Несмотря на достаточно высокую степень техногенной нивелировки поверхности, для территории Витебска характерно значительное разнообразие рельефа. Располагаясь в пределах денудационной столово-останцовой равнины на высотах от 125 до 217 м над уровнем моря, город представляет собой сочетание различных форм рельефа, сформированных в ходе сложной динамики отступающего позднеплейстоценового поозерского ледникового покрова и деградации крупных приледниковых бассейнов. В настоящее время геоморфологические процессы в городе обусловлены, прежде всего, флювиальной морфоскульптурой и техногенезом [2]. Основными элементами современного орографического рисунка городской территории являются: 1) долины рек Западная Двина, Лучеса и Витьба (абсолютные высоты 125-140 м); 2) пологая флювиогляциальная равнина правобережья Западной Двины (140-144 м); 3) пологоволнистая моренная равнина правобережья Западной Двины (155-180 м); 4) пологоволнистая флювиогляциальная равнина левобережья Западной Двины (145-185 м); 5) слабоволнистая, местами плоская, озерно-ледниковая низина в северо-восточной части города (145-150 м); 6) пологоволнистая, местами холмисто-увалистая, конечно-моренная возвышенная равнина левобережья Западной Двины (абсолютные высоты 145-180 м в северной части города и 165-217 м в междуречье Витьбы и Лучесы) (рис. 1).

В климатическом отношении Витебск расположен в зоне умеренного умеренно-континентального климата. В последние десятилетия наблюдаются стабильные отклонения климатических характеристик в сторону потепления и увлажнения. Среднегодовая температура воздуха по многолетним данным составляет $+5,1^{\circ} \mathrm{C}$, а среднее значение за последние 10 лет $+7,05^{\circ} \mathrm{C}$. Средняя температура января соответственно $-7,9^{\circ} \mathrm{C}$ и $-6,2^{\circ} \mathrm{C}$, июля $+17,8^{\circ} \mathrm{C}$ и $+19,6^{\circ} \mathrm{C}$. Количество атмосферных осадков по годам колеблется в довольно широких пределах - от 407 до 959 мм. В среднем за год по многолетним данным (за 70 лет) выпадает 665 мм осадков, при осреднении за последние 10 лет - 789 мм. В течение всего года преобладают ветры юго-западных рум- бов, в весенне-летний период постепенно возрастает доля западных ветров. С апреля по август велика роль северо-восточных ветров. Наиболее ветреная погода в городе устанавливается в октябре-январе. Однако максимальной скорости ветер достигает весной и в первой половине лета.

Приведенные значения климатических характеристик соответствуют данным климатических справочников и метеослужбы аэропорта «Витебск», расположенного в 10 километрах к юго-востоку от города на высоте 200 м, что и позволяет сравнивать его зональные характеристики с другими регионами страны. Что же касается оценки роли рельефа города Витебска на климатические параметры. То таких работ до сих пор не выполнялось. Основываясь на базовых работах по микроклимату [3], строительной климатологии, новейших исследованиях в области экологии и климата городской среды $[1,4]$, нами предпринята попытка восполнить этот пробел.

Под микроклиматом понимают локальные особенности климата, обусловленные неоднородностью строения подстилающей поверхности и существенно изменяющиеся уже на небольших расстояниях. Кроме микроклимата выделяют также и местный климат, или мезоклимат. Граница между микроклиматом и мезоклиматом проводится на основании масштабов неоднородностей подстилающей поверхности.

Выделение границ между мезо- и микроклиматом довольно проблематично. Большинство авторов используют только понятия «микроклимат». Разделение мезо- и микроклиматов в пределах городских территорий довольно удобно. Поскольку масштабность метеорологических реакций можно сопоставлять с территориальными единицами микрорайонов, районов или участками, привязанными к крупным мезоформам рельефа. Наиболее разработанное деление климата представлено в работах Е.Н. Романовой $[5,6]$. Согласно этому автору, мезоклимат - это климат сравнительно небольших территорий, достаточно однородных по природным условиям. Он в большей степени определяется особенностями подстилающей поверхности на конкретной территории. Такими особенностями являются рельеф, растительный покров, городская застройка. Их влияние наиболее заметно в нижнем слое атмосферы до высоты сотен метров.

Цель статьи - рассмотреть особенности климатических условий территории Витебска на уровне мезоклимата, оценить роль рельефа в его формировании. 


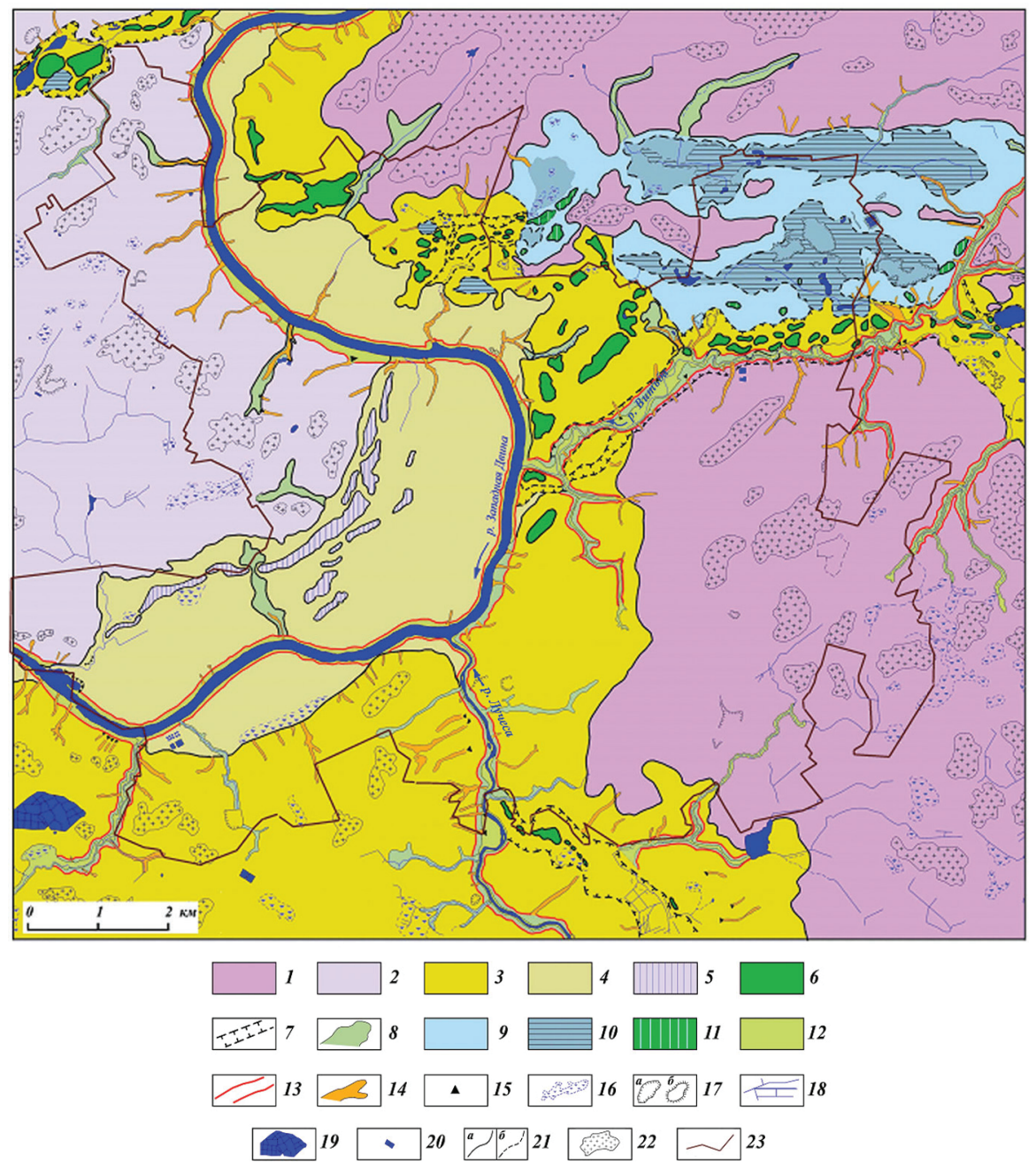

Гляциальный рельеф: 1 - пологоволнистая, местами холмисто-увалистая, конечно-моренная возвышенная равнина поозерского возраста; 2 - пологоволнистая моренная равнина поозерского возраста. Флювиогляциальный рельеф: 3 - пологоволнистая флювиогляциальная равнина поозерского возраста; 4 - пологая флювиогляциальная равнина поозерского возраст; 5 - останиь отседания в пределах флювиогляцильной равнинь; 6- поозерские камовые массивы; 7 -маргинальные ложбины стока; 8-ложбины стока талых ледниковых вод. Лимноглячиальный рельеф: 9 - слабоволнистая, местами плоская озерно-ледниковая низина поозерского возраста; 10 - плоские заболоченные и заторфованные поверхности поозерских озерных котловин; 11 - поозерские лимнокамы. Флювиальный рельеф: 12 - поймы современной речной сети; 13 - глубоковрезанные речные долины голоченового возраста; 14 - современная овражно-балочная сеть; 15 - современные конусы выноса. Биогенный рельеф: 16 - современные плоские заторфованные и заболоченные поверхности. Техногенный рельеф: 17 - карьеры (а) и насыпи (б); 18 - каналь;; 19 - поля фильтрачии; 20 - пруды. Другие обозначения. 21 - границы однородных генетических поверхностей: а) четкие, б) нечеткие. 22 - денудационные поверхности (плакоры), 23 - граница города

[Glacial relief: 1 - gently undulating, in places hilly-ridged, finite moraine upland plain of Poozersky age; 2 - gently undulating moraine plain of Poozersky age. Fluvioglacial relief: 3 - gently undulating fluvioglacial plain of Poozersky age; 4 - gentle fluvioglacial plain of Poozersky age; 5 - remnants of subsidence within the fluvioglacial plain; 6-Poozersky kam massifs; 7 - marginal runoff troughs; 8-troughs of melt glacial waters runoff. Limnoglacial relief: 9 -slightly wavy, in places flat lacustrine-glacial lowland of Poozersky age; 10 - flat swampy and peaty surfaces of the lake basins of the lake; 11 - Poozersky limnokams. Fluvial relief: 12 -floodplains of the modern river network; 13 - deeply cut river valleys of the Holocene age; 14 - modern ravine and girder network; 15 - modern fan cones. Biogenic relief: 16-modern flat peat and waterlogged surfaces. Technogenic relief: 17-quarries (a) and embankments (b); 18 - channels; 19 - filtration fields; 20 - ponds. Other designations. 21 - boundaries of homogeneous genetic surfaces: a) clear, b) indistinct. 22 - denudation surfaces (plakors), 23 - city border]

Puc. 1. Геоморфологическая карта территории Витебска и его окрестностей

[Fig. 1. Geomorphological map of the area of Vitebsk and its environs]

Вестник ВГУ, Серия: География. Геоэкология, 2021, № 3, 13-24 
Для достижения поставленной цели были построены базовая векторная карта и цифровая модель рельефа (ЦМР) территории города, проведена оценка ведущих климатообразующих факторов - экспозиции и крутизны склонов, наличие четко выраженных форм мезорельефа, тип застройки, присутствие (или отсутствие) крупных водотоков и водоемов, а также «зеленых» массивов. Составлена характеристика климата для точек стационарных постов метеонаблюдений. На завершающем этапе исследований на основе полученных данных с помощью аналитического инструментария ГИС была создана схематическая карта мезоклиматических условий территории города.

\section{МАТЕРИАЛЫ И МЕТОДЫ}

Цифровая модель рельефа создавалась на базе векторизации топографических карт 1990-х годов масштаба 1:10000 - 1:100000, данных открытых интернет-источников, земельно-информационной системы Республики Беларусь и материалов собственных полевых исследований. В целях подбора наилучшего варианта базовой модели. ЦМР строилась в двух вариантах - с использованием возможностей модуля Vertical Mapper геоинформационной платформы MapInfo и с помощью инструментов модуля Spatial Analyst ArcGIS. Определение крутизны и экспозиции склонов также проводилось аналитическими средствами, которые предоставлялись соответствующими модулями платформ ArcGIS и MapInfo. В результате проделанной paботы был сделан вывод об отсутствии серьезных различий между полученными моделями.

Для создания базовых слоев векторной карты города нами использовалась нейронная сеть, что позволило не только с высокой точностью выполнить графику, но и создать базу атрибутивных характеристик объектов карты в полуавтоматическом режиме. Именно атрибутивные данные векторной карты, наряду с результатами дешифрирования материалов спутниковой и аэрофотосъемки, послужили для установления различий отражающей способности поверхностей.

Систематические метеонаблюдения на территории Витебска ведутся лишь на четырех стационарных постах, что явно недостаточно для определения не только микро-, но и мезоклиматических особенностей. Однако, определив степень влияния на метеопараметры указанных выше характеристик и соотнеся их с маркерными показателями стационарных метеопостов, возможно получить картину отклонений климатических характеристик от зональных для любой территории.

\section{РЕЗУЛЬТАТЫ И ОБСУЖДЕНИЕ}

Основой анализа влияния рельефа и связанных с ним особенностей городской среды на климат Витебска стали материалы по отдельным природным, административно-хозяйственным и коммунальным элементам, собранные в геоинформационую систему. Основой ГИС является базовая векторная карта города, состоящая из четырех слоев - «Гидрография», «Дорожная сеть», «Застройка» и «Растительность». В каждом слое содержится информация о размерах, типологии и ряде других атрибутивных характеристиках объектов. Например, в базе данных «Застройка» собраны данные о назначении, этажности, материале построек, что может быть использовано при оценке влияния на ветровой и температурный режим.

Построение цифровой модели рельефа проводилось на основе сканов бумажных топографических карт, математическая основа которых отличается от таковой для современных картографических источников информации. Несмотря на то, что встроенные возможности преобразования координатных систем не позволили автоматически совместить данные по рельефу, застройке, дорожной сети, гидрографии и растительности, окончательное сведение слоев было выполнено в полуавтоматическом и ручном режимах. Это позволило достаточно корректно привязать данные о городской среде к цифровой модели рельефа (рис. 2).

На следующем этапе цифровая модель рельефа города послужила основой для построения картографических моделей экспозиции и крутизны склонов. Эти параметры рельефа в значительной степени определяют внутригородские различия метеорологических характеристик (рис. 3).

Для большей наглядности и упрощения последующего анализа для карты экспозиции склонов была выбрана градация с минимальным количеством экспозиций (север, юг, запад, восток), а градация крутизны склонов проведена так, чтобы разделить участки, где уклон значителен и достаточен для влияния на климатические характеристики и территории с пологим рельефом.

Далее на основе совмещения производных карт экспозиции и крутизны склонов с ЦМР определялись границы основных орографических элементов (мезоформ) поверхности рельефа города. Их характеристики, такие как высота, расчлененность, взаимное расположение, ориентированность по отношению к воздушным потокам, по нашему мнению, являются основными факторами, определяющими возникновение в пределах 
Витебска заметных различий на уровне мезоклимата. На первом этапе совмещенного анализа при наложении карты крутизны склонов и ЦМР были выделены разновысотные выровненные участки, которые соответствовали вершинным поверхностям возвышенностей, впадинам и котловинам различной степени замкнутости. Затем по рельефной карте нами обособлялись четко очерченные долины рек Западной Двины, Лучесы и Витьбы и оврагов. Оставшиеся территории по данным карты экспозиции склонов выделялись как склоновые поверхности (от пологих до крутых $-3,7-15^{\circ}$ и более) с различной экспозицией: северной, южной, западной и восточной.

Таким образом, в результате проведенного геотопологического анализа городской территории были выделены типы местоположений, в пределах которых особенности рельефа обусловлива- ют формирование особого температурного и ветрового режима, создают четкие отличия климатических параметров по сравнению с зональной плоской поверхностью. Ниже приведена классификация поверхностей по их местоположению, используемая нами в дальнейшем для выявления мезоклиматических особенностей в пределах территории Витебска (рис. 4).

Такая классификация не является исчерпывающей, но вполне подходит для оценки влияния рельефа на городской климат мезоуровня. В результате вышеперечисленных действий была получена базовая карта местоположений поверхностей рельефа для вычисления мезоклиматических отклонений в их пределах. После некоторой генерализации данных и наложения показателей отражающих способности поверхности была получена схематическая карта города, на которой

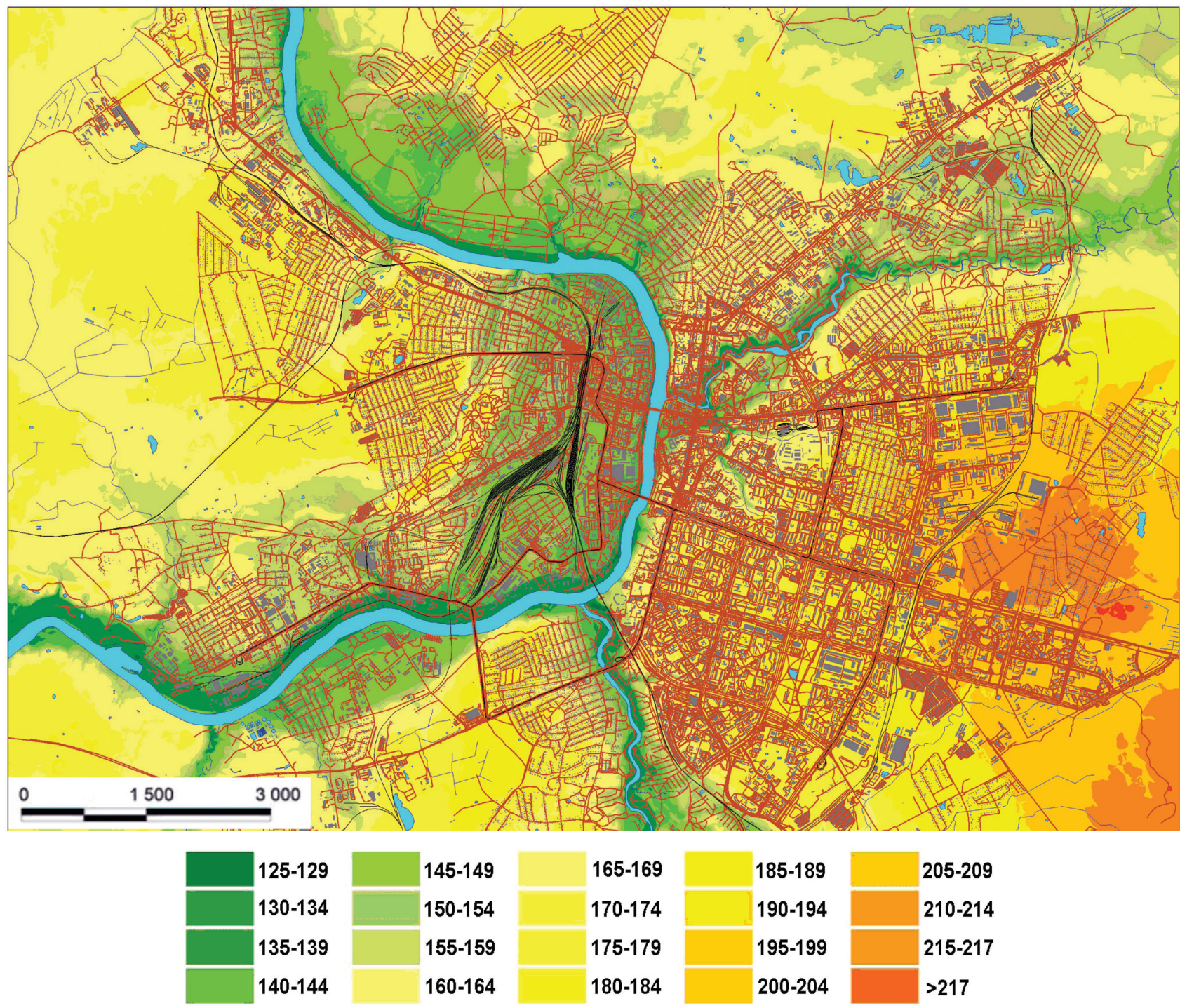

Рuc. 2. Цифровая модель рельефа территории Витебска со слоями гидрографии, дорожной сети и застройки

[Fig. 2. Digital relief model of the area of Vitebsk with layers of hydrography, road network and buildings]

Вестник ВГУ, Серия: География. Геоэкология, 2021, № 3, 13-24 


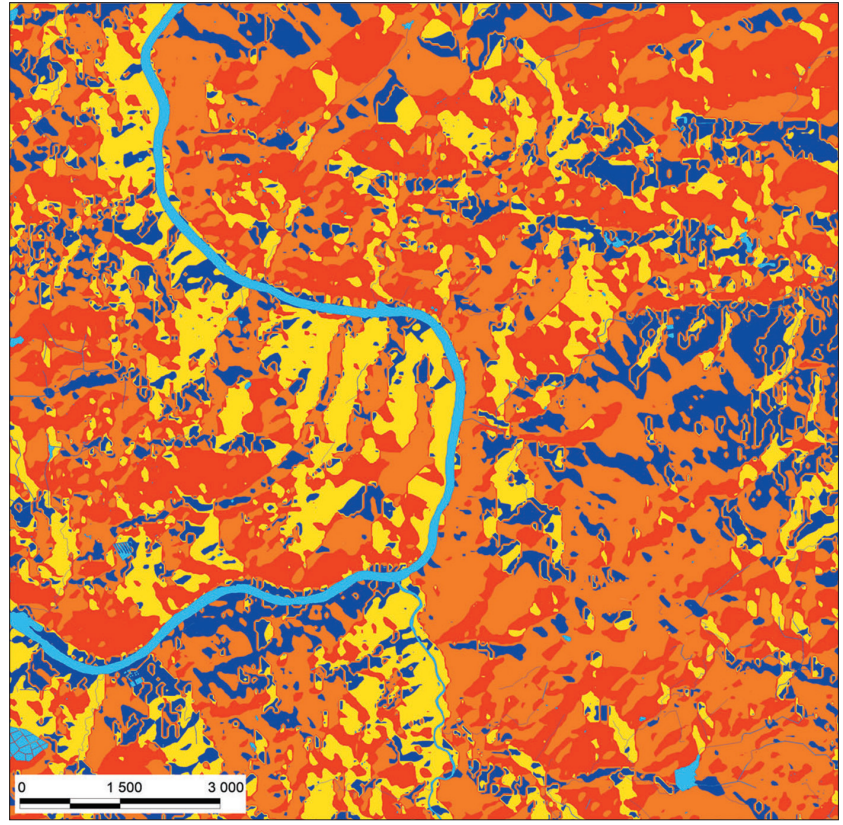

(a)

Экспозиция склонов, град. (азимуты) [Slope exposure, deg. (azimuths)]

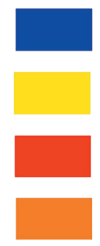

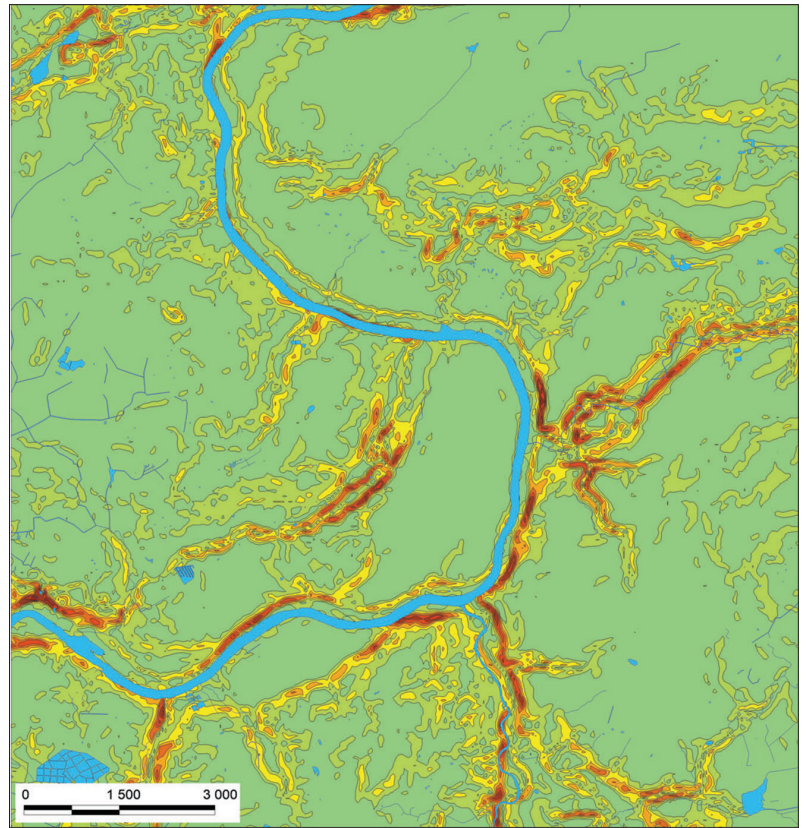

(б)

Крутизна склонов, град. [Steepness of the slopes, deg.]

\begin{tabular}{|c|c|}
\hline$<1,8$ & $9,4-11,2$ \\
\hline $1,8-3,7$ & $11,2-13,1$ \\
\hline $3,7-5,6$ & $13,1-15.0$ \\
\hline $5,6-7,5$ & $15,0-16,9$ \\
\hline $7,5-9,4$ & $>16,9$ \\
\hline
\end{tabular}

Puc. 3. Карты экспозиции (а) и крутизны (б) склонов территории Витебска [Fig. 3. Maps of the exposition and steepness of the slopes of the area of Vitebsk]

выделены территории, обладающие особыми мезоклиматическими условиями (рис. 4). Следует отметить, что учет более полного спектра параметров, влияющих на климат (особенности отдельных зданий, ориентировка улиц, различие верхних, средних и нижних частей склонов и т.д.), и переход работы на «микроклиматический» уровень автоматически привел бы к лавинообразному нарастанию данных, дроблению и потере возможности адекватного обобщения и районирования территории в принципе.

Следующий этап работ касался анализа внутригородских различий метеопараметров. Исходной информацией послужили материалы, предоставленные Витебским областным центром по гидрометеорологии и мониторингу окружающей среды. Нами были проанализированы метеоданные за годовой период (с января по декабрь 2016 г.) в четырех вариантах местоположений по данным стационарных пунктов метеонаблюдений. Сравнивались температурный режим, атмосферное давление, сила и направление ветра (атмосферные осадки не анализировались).
Таким образом, в результате проведенного геотопологического анализа городской территории были выделены типы местоположений, в пределах которых особенности рельефа обусловливают формирование особого температурного и ветрового режима, создают четкие отличия климатических параметров по сравнению с зональной плоской поверхностью. Ниже приведена классификация поверхностей по их местоположению, используемая нами в дальнейшем для выявления мезоклиматических особенностей в пределах территории Витебска (рис. 4).

Такая классификация не является исчерпывающей, но вполне подходит для оценки влияния рельефа на городской климат мезоуровня. В результате вышеперечисленных действий была получена базовая карта местоположений поверхностей рельефа для вычисления мезоклиматических отклонений в их пределах. После некоторой генерализации данных и наложения показателей отражающих способности поверхности была получена схематическая карта города, на которой 


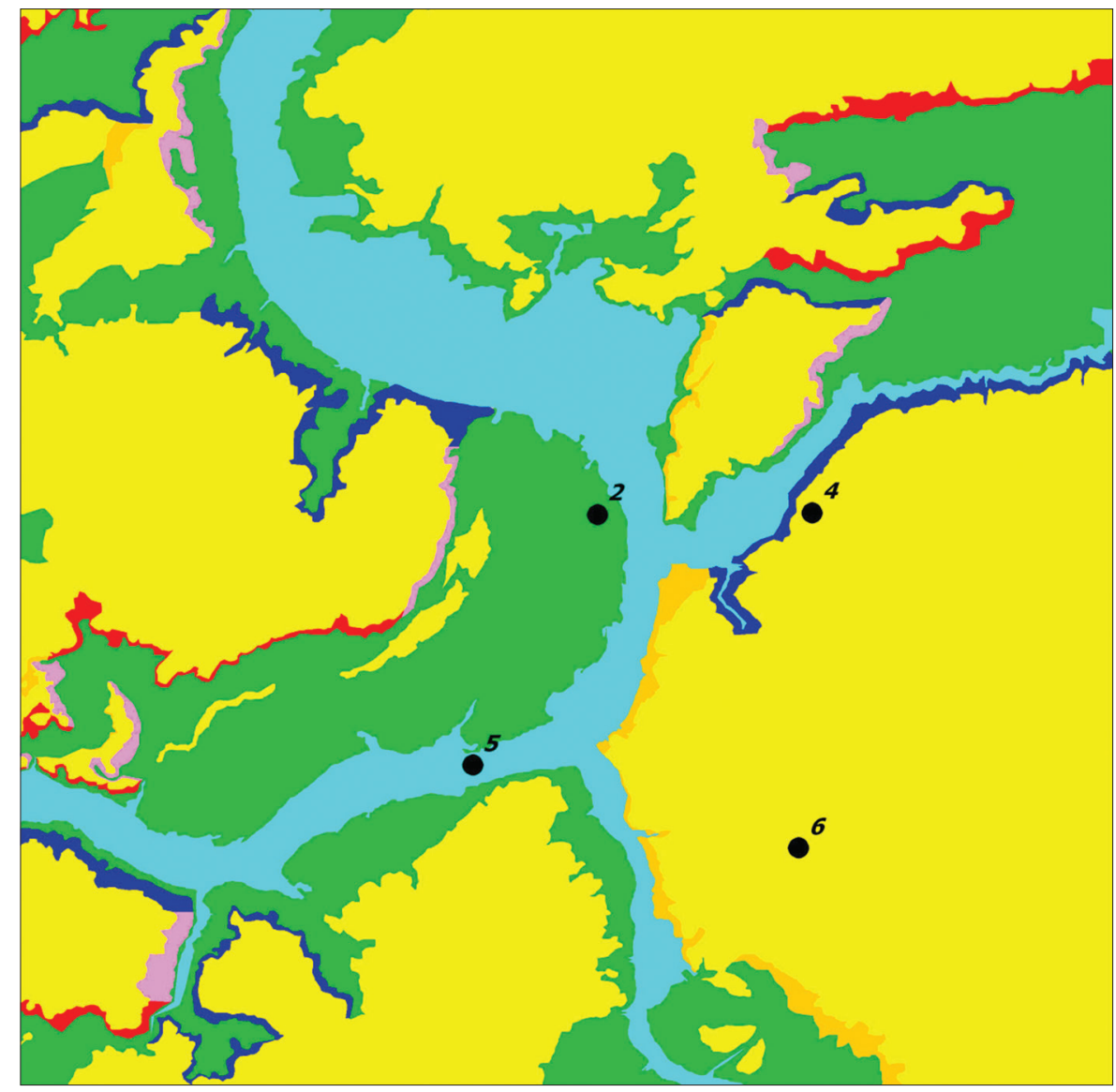

- пункты наблюдений [observation point and its number] вериинные поверхности (плакоры) [top surfaces (plakors)] долины рек и проветриваемые котловины [river valleys and ventilated valleys] низины, замкнутыле впадины и котловинь [lowlands, closed depressions and hollows] склоны северной экспозищии [northern exposure slopes] склоны южной экспозиции [southern exposure slopes] склоны западной экспозиции [western exposure slopes] склоны восточной экспозиции [eastern exposure slopes]

Puc. 4. Схематическая карта мезоклиматических условий Витебска (характеристика стационаров метеонаблюдений и мезоклиматов города приведена в тексте)

[Fig. 4. Schematic map of mesoclimatic conditions of Vitebsk (characteristics of meteorological observation stations and mesoclimates of the city are given in the text)]

выделены территории, обладающие особыми мезоклиматическими условиями (рис. 4). Следует отметить, что учет более полного спектра параметров, влияющих на климат (особенности отдельных зданий, ориентировка улиц, различие верхних, средних и нижних частей склонов и т.д.), и переход работы на «микроклиматический» уровень автоматически привел бы к лавинообразному нарастанию данных, дроблению и потере возможности адекватного обобщения и районирования территории в принципе.

Следующий этап работ касался анализа внутригородских различий метеопараметров. Исходной информацией послужили материалы, пре- доставленные Витебским областным центром по гидрометеорологии и мониторингу окружающей среды. Нами были проанализированы метеоданные за годовой период (с января по декабрь 2016 г.) в четырех вариантах местоположений по данным стационарных пунктов метеонаблюдений. Сравнивались температурный режим, атмосферное давление, сила и направление ветра (атмосферные осадки не анализировались).

Предварительная обработка результатов наблюдений показала, что ряды метеоданных трех из четырех стационарных пунктов за анализируемый период характеризуют различные мезоклиматические условия. Отметим, что проведенный 
нами анализ имел целью не охарактеризовать стандартные климатические условия тех или иных местоположений, а выявить закономерности в различиях метеопараметров сравниваемых локаций между собой и зональными параметрами.

Характеристика стационаров метеонаблюдений. Стационарный пункт метеонаблюдений (ПМ) № 6 по адресу город Витебск, проспект Победы, д. 20 характеризуется условиями наиболее сходными по характеру циркуляции с зональными. Однако под влиянием «острова тепла» имеет несколько другие метеорологические характеристики при сохранении общего тренда. Параметры данного стационара приняты нами за «типо- вые» для мезоклимата равнинных возвышенных участков (плакоров) городских территорий. Пункт расположен в западной части пологоволнистой конечно-моренной возвышенной равнины на высоте 178 м над уровнем моря. Это зона высотной застройки, но сам пункт расположен на открытой местности. Анализ температурных данных показывает, что на плакоре (в черте города) среднегодовая температура была на $0,85^{\circ}$ выше, чем в окрестностях Витебска. При этом четко видно, что летом разница температур между городом и зональными условиями значительно выше, чем в осенне-зимний период (от $2^{\circ}$ до $0,25^{\circ}$ соответственно) (рис. 5).

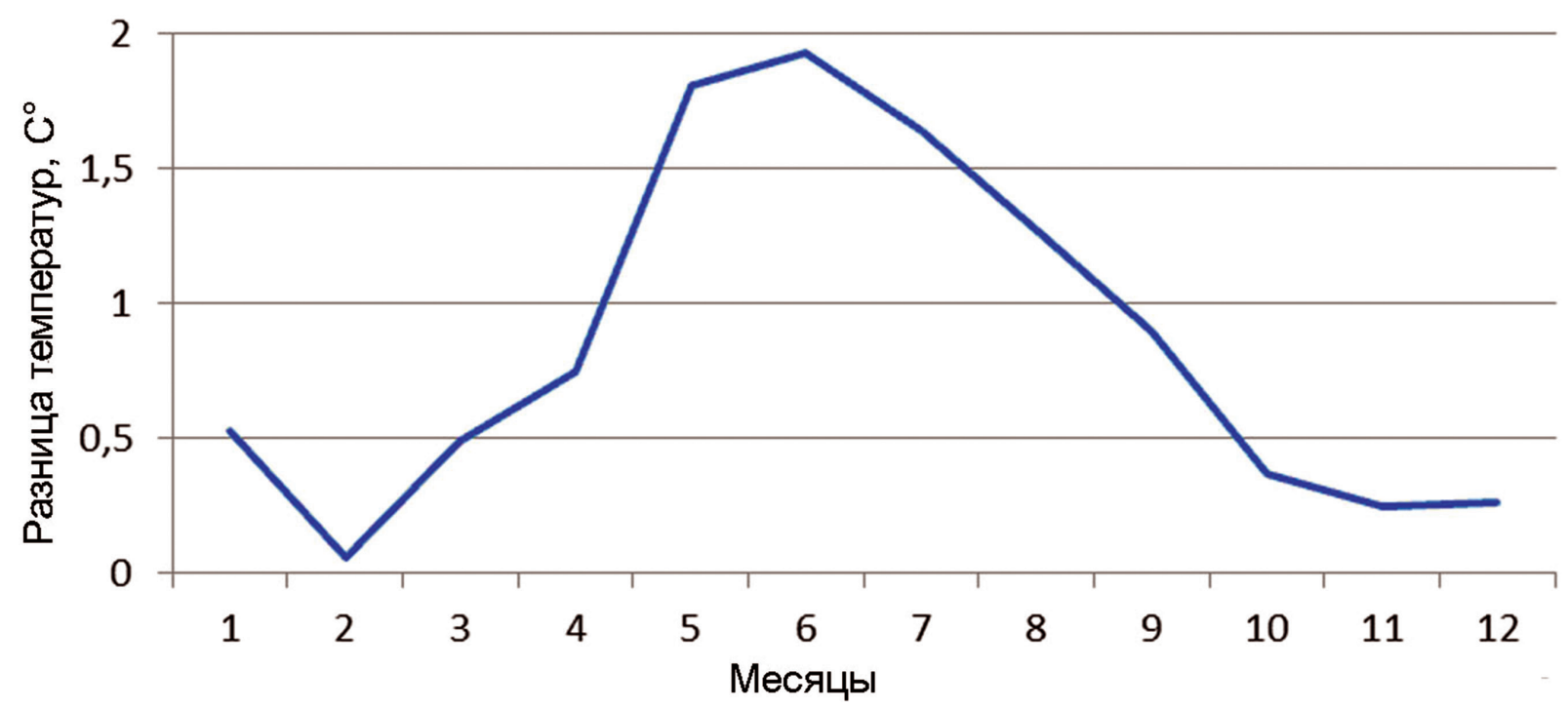

Pис. 5. Разница температур, формирующаяся между зональными (стационар «Аэропорт») и городскими условиями (ПМ № 6) под воздействием эффекта «острова тепла»

[Fig. 5. The temperature difference formed between the zonal ("Airport" station) and urban conditions (meteorological observation point No. 6) under the influence of the "heat island" effect]

Атмосферное давление в течение всего года на участке стационара № 6 ниже, чем за городом в среднем на 1,6 гПа, при этом сезонных или иных закономерных различий в разности показателей давления нами не выявлено. Скорость ветра на плакоре в городе оказалась стабильно выше по сравнению с зональными условиями. Разница в среднемесячных показателях силы ветра в летний период доходила до 0,5 м/с, а в холодный - не превышала 0,1-0,2 м/с. Что касается направления ветров, то и в городе, и за городом более 50 \% времени преобладали ветры юго-западных - западных румбов, и около 25 \% приходилось на румбы северного - северо-восточного направления. В летний период отмечена высокая повторяемость ветров восточных румбов.

Для оценки внутригородских различий климатические параметры других стационаров срав- нивались с показателями ПМ № 6. Пункт № 5 (по ул. Космонавтов) расположен в расширяющейся части долины р. Западная Двина на высоте около 142,5 м над уровнем моря. Особенности мезоклиматических условий определяются здесь относительной замкнутостью котловины, влиянием реки, плотной среднеэтажной жилой и промышленной застройкой. Исходя из названных характеристик, стационар может быть принят как типовой для мезоклимата замкнутых впадин и котловин. Тренд температур здесь мало отличается от ПМ № 6; среднегодовая температура практически одинакова. Разница составляет всего $0,1^{\circ} \mathrm{C}$. В то же время летом среднемесячные температуры в котловине фиксировались почти на градус ниже, а зимой на несколько десятых градуса выше (рис. 6, a). 
Атмосферное давление в ПМ № 5 стабильно в течение всего года. Зарегистрировано отличие от ПМ № 6 в среднем на 3-3,5 гПа, что, по всей вероятности, обусловлено разностью абсолютных высот. Мезоклимат котловин от мезоклимата плакоров характеризуется значительно меньшими скоростями ветра: в среднем за год на 0,75 м/с, a большую часть года - более чем на 1 м/с. При экстремальных значениях силы ветра эта разница еще больше - до 2,2 м/с. Штилевая погода в котловинах повторялась в 6,5 раз чаще, чем на плакоре. Роза ветров на ПМ № 5 резко отличается от ПМ № 6 господством ветров восточных румбов, что, на наш взгляд, объясняется особенностями рельефа.

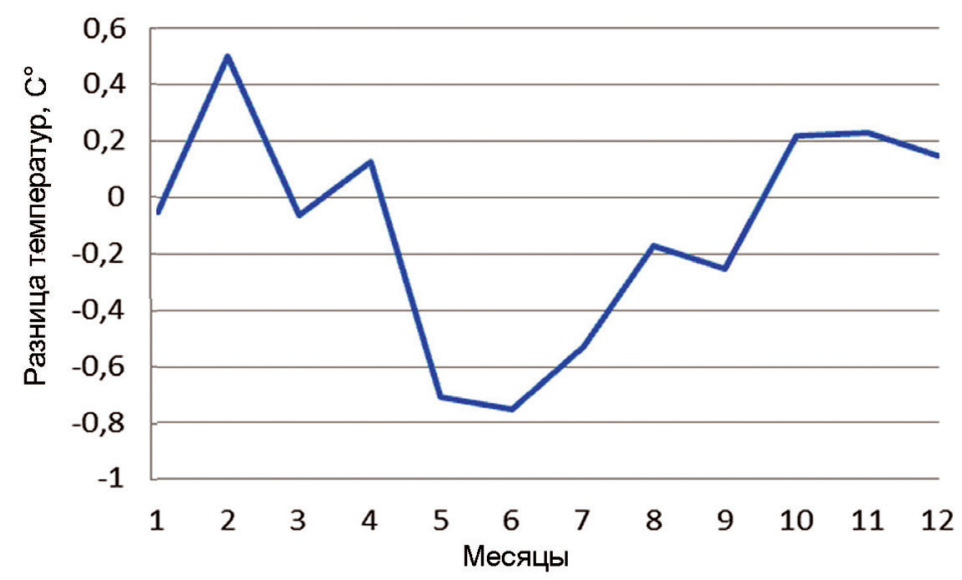

(a)

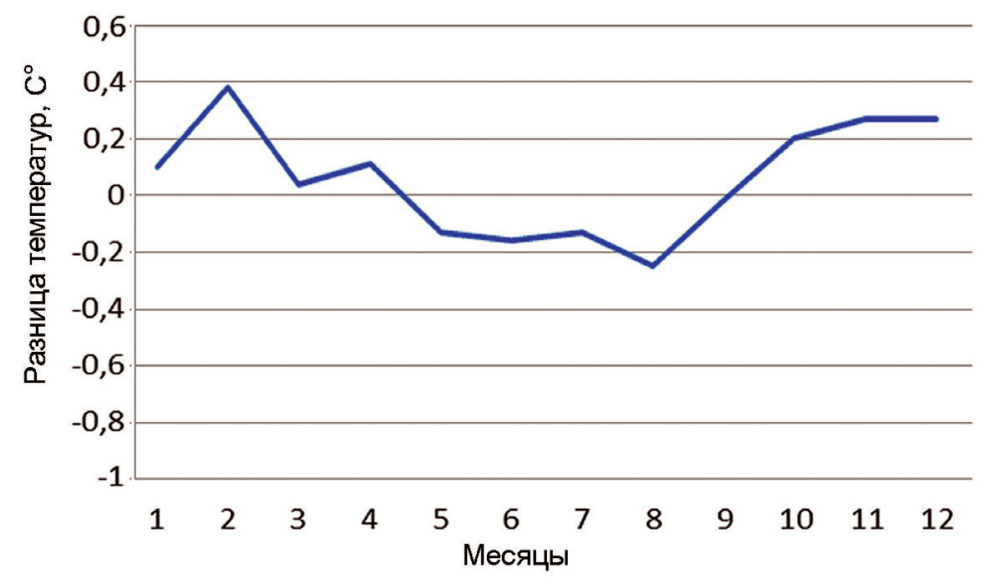

(б)

Рис. 6. Разница температур между пунктами метеонаблюдений № 5 и 6 (а) и №2 и 6 (б)

[Fig. 6. Temperature difference between meteorological observation points No. 5 and 6 (a) and No. 2 and 6 (b)]

Стационарный ПМ № 2 (ул. М. Горького, 44) расположен в долине р. Западная Двина по правому берегу на высоте около 135 м над уровнем моря. Долина реки здесь четко ориентирована с запада на восток. Застройка не плотная. В основном одно-двухэтажная промышленно-складская зона. Анализ метеоданных показывает, что климатические характеристики стационаров ПМ №2 и 6 очень близки. Сходны и розы ветров. Практически одинаковы температурные параметры - разница среднемесячных температур не превышает $0,2-0,3^{\circ}$, а среднегодовых менее $0,05^{\circ}$ (рис. 6, б). Из особенностей метеопараметров стабильно прослежи- вается меньшая сила ветра (в среднем на 0,5 м/с) и давление (в среднем на 4 ГПа) в долине реки.

Как следует из рисунка 4 два из четырех метеостационаров (ПМ №4 и 6) оказались на территориях с одинаковыми условиями с точки зрения особенностей рельефа - относительно выровненные поверхности, представляющие пологую возвышенную равнину. Несмотря на то, что другие факторы, влияющие на условия формирования климата на стационаре № 4 (проспект Людникова), представлены иначе, чем на ПМ № 6 (плотная жилая многоэтажная застройка, близость долины реки Витьба, относительно большие массивы древесной и кустарниковой 
растительности), разница в динамике и абсолютных показателях метеопараметров здесь минимальна. Это, по нашему мнению, подтверждает вывод о том, что рельеф является ведущим климатообразующим фактором на мезоуровне.

Характеристика мезоклиматов. Основываясь на данных метеопараметров стационаров, результатах работ Е.Н. Романовой $[5,6]$ и с учетом классификации местоположений, можно утверждать, что в границах города Витебска действительно существуют значимые различия на уровне мезоклимата, которые могут существенно влиять на качество жизни населения и особенности развития градостроительства. Отметим, что наибольшие различия между типами мезоклиматов фиксируются для их экстремальных значений, в то время как осредненные (среднесуточные, среднемесячные) величины отличаются незначительно.

Ниже охарактеризуем особенности мезоклиматов, выделенных нами на территории Витебска.

Мезоклимат равнинных возвышенных участков (плакоров). Он характерен для большей части междуречья Лучесы и Витьбы, района между улицами Гагарина - Великолукский тракт - Сельская, южной окраины города между улицами Зеленогурская и Аксановская, а также территории к северо-западу от Юрьевой горки. Для данного мезоклимата характерны условия близкие по типу циркуляции с зональными. Зимой минимальные температуры здесь могут быть несколько выше, чем в среднем по городу, но в целом температурный режим можно принять как среднегородской. Направление и скорость ветра близки к средним зональным значениям. Но скорость ветра может меняться в среднем от 1,2 до 1,5 раз выше фиксируемой за пределами города. Зимой господствуют ветры юго-западных румбов. Летом усиливается роль юго-восточных ветров. Реальная роза ветров в значительной степени контролируется особенностями застройки и ориентировкой крупных городских магистралей, особенно в многоэтажных районах междуречья Лучесы и Витьбы.

Мезоклимат котловин и выровненных низин. Занимает широкую полосу на правобережье Западной Двины (районы железнодорожного вокзала, Марковщины, домостроительного комбината) и северо-восточной части города к северу от долины реки Витьба (верхняя частью района ул. Гагарина). В отличие от возвышенных равнин экстремальные значения температур здесь на 2-2,5 ниже средних величин. Особенность мезоклимата - значительное снижение скорости ветра. Например, среднегодовая его величина здесь на 0,5 м/с меньше, чем на пла- корах. Более сглаженной выглядит роза ветров, хотя преобладание юго-западных ветров остается заметным. Некоторое влияние на климат оказывает наличие водных объектов, что способствует увеличению влажности и частоте повторяемости туманов.

Мезоклимат долин рек и проветриваемых понижений. Распространен полосой до нескольких сотен метров шириной вдоль рек Западная Двина, Витьба и Лучеса. Отличительная черта мезоклимата - мягкий температурный режим (малые значения перепадов температур в течение суток и в течение более длительных периодов). За весь год в долине реки четко прослеживается стабильно меньшая сила ветра (в среднем на 0,5 м/с) и давление (в среднем на 4 гПа). Что же касается направления ветра, то оно контролируется простиранием долин рек и склоновой циркуляцией, но влияние зональных черт в годовой розе ветров сохраняется.

Мезоклиматы склонов. Климаты, связанные с экспозицией и крутизной склонов на территории Витебска развиты слабо. Климат пологих склонов возвышенностей очень близок по метеоданным к мезоклиматическим характеристикам плакоров и их определение как склоновых в рамках предложенного районирования нецелесообразно. Однако, отрицать климатообразование на склонах нельзя. Такие условия формируются повсеместно по периферии крупных речных долин и замкнутых котловин в полосе шириной 100-300 м. Основной отличительной чертой их является усиление ветра и развитие склоновой циркуляции.

\section{ЗАКЛЮЧЕНИЕ}

В результате проведенных исследований нами установлено, что рельеф Витебска относится к ведущему климатообразующему фактору. Особое значение на формирование мезоклимата оказывают экспозиция и уклон поверхностей, влияющие на изменчивость скорости, направления ветра, давления и температурного режима. Для территории Витебска, исходя из сопряженного анализа рельефа и метеорологических условий, установлено семь вариантов мезоклимата. Четыре характерны для ярко выраженных склонов разной экспозиции и представлены очень ограниченно. На большей части территории города, занятой выровненными возвышенными поверхностями, наблюдаются условия близкие к зональным с отклонениями, обусловленными влиянием «острова тепла». Особые мезоклиматические условия формируются в котловинах и крупных долинах, что проявляется в снижении скоростей ветра, более плавном ходе средних и увеличении экстремальных значений температур. 


\section{СПИСОК ЛИТЕРАТУРЫ}

1. Акимов Л.М., Виноградов П.М., Акимов Е.Л. Комплексная оценка экологической обстановки с учетом состояния атмосферы и функционально-планировочной структуры города // Вестник Воронежского государственного университета. Серия: География. Геоэкология, 2014, № 4, с. 57-67.

2. Галкин А.Н., Тимошкова А. Д., Красовская И. А., Торбенко А.Б. Особенности проявления современных экзогенных процессов на территории Витебска // Літасфера, 2007, № 1 (26), с. 73-77.

3. Несмелова Е.И., Филиппова М.Г. Микроклиматология. Москва: Географ. фак. МГУ, 2006. 186 с.

4. Исаков С.В. Использование геоинформационных систем для комплексной оценки микроклиматических особенностей территории // Метеоспектр, 2013, с. 80-85.
5. Романова Е.Н., Гобарова Е. О., Жильцова Е.Л. Методы использования систематизированной климатической и микроклиматической информации при развитии и совершенствовании градостроительных концепций. СПб.: Гидрометеоиздат, 2000. 160 с.

6. Романова Е.Н., Гобарова Е.О., Жильцова Е.Л. Методы мезо- и микроклиматического районирования для целей оптимизации размещения сельскохозяйственных культур с применением технологии автоматизированного расчета. СПб.: Гидрометеоиздат, 2003. 104 с.

Конфликт интересов: Авторы декларируют отсутствие явных и потенциальных конфликтов интересов, связанных с публикацией настоящей статьи.

Поступила в редакциюю 26.11.2020 Принята к публикации 03.09.2021

\title{
GEOGRAPHY
}

UDC 551.4.08 (476.5):57.045

DOI: https://doi.org/10.17308/geo.2021.3/3596

ISSN 1609-0683

\section{Peculiarities of the Influence of Vitebsk's Relief on Climatic Parameters}

\author{
A. B. Torbenko ${ }^{1 \bowtie}$, A.N. Galkin ${ }^{1}$, D. V. Novikov ${ }^{1}$, I. N. Ivanova-Logvinova ${ }^{2}$ \\ ${ }^{1}$ Vitebsk State University named after P. M. Masherov, Republic of Belarus \\ (33, Moskovsky Ave., Vitebsk, 210038) \\ ${ }^{2}$ Vitebsk Regional Centre for Hydrometeorology and Environmental Monitoring, Republic of Belarus \\ (81, Frunze Ave., Vitebsk, 210101)
}

\begin{abstract}
The purpose is to consider the peculiarities of the mesoclimatic conditions of the area of Vitebsk, to assess the role of the relief in its formation.

Materials and methods: To achieve this purpose, a base vector map and a digital relief model of the city area were built. The main climate-forming factors (exposure and steepness of slopes, mesorelief forms, type of development, presence or absence of streams and reservoirs, arrays of tree and shrub vegetation) were assessed. Results: a geotopological analysis of the urban area was carried out. The types of locations were identified, within which the features of the relief determine a special temperature and wind regime, form clear differences in climatic parameters in comparison with the surrounding areas. A base map of the locations of the city's relief surfaces was created for calculating mesoclimatic deviations within them, and on its basis a schematic map of the mesoclimatic conditions of Vitebsk was built; these conditions are characterised.

Conclusions: Based on the conjugate analysis of the relief and meteorological conditions, seven variants of the mesoclimate were established for the city. Moreover, four of them are represented very limitedly. In most of the area of Vitebsk, occupied by leveled elevated surfaces, the conditions are close to zonal (outside the city) with deviations due to the influence of the "heat island". Special mesoclimatic conditions are formed in depressions and large valleys, which is manifested in a decrease in wind speeds, a smoother course of average temperatures and an increase in extreme temperatures.
\end{abstract}

(C) Torbenko A. B., Galkin A. N., Novikov D. V., Ivanova-Logvinova I. N., 2021

\ Andrey B. Torbenko, e-mail: torbenko_a@mail.ru

cc) (i) The content is available under Creative Commons Attribution 4.0 License.

Вестник ВГУ, Серия: География. Геоэкология, 2021, № 3, 13-24 
Key words: relief, exposure of slopes, steepness of slopes, geographic information system, digital elevation model, mesoclimatic conditions.

For citation: Torbenko A. B., Galkin A. N., Novikov D. V., Ivanova-Logvinova I. N. Peculiarities of the Influence of Vitebsk's Relief on Climatic Parameters. Vestnik Voronezskogo gosudarstvennogo universiteta. Seria: Geografia. Geoekologia, 2021, no. 3, pp. 13-24 (In Russ.). DOI: https://doi.org/10.17308/geo.2021.3/3596

\section{REFERENCES}

1. Akimov L.M., Vinogradov P.M., Akimov E.L. Kompleksnaya otsenka ekologicheskoy obstanovki s uchetom sostoyaniya atmosfery i funktsional'no-planirovochnoy struktury goroda [Comprehensive assessment of the environmental situation, taking into account the state of the atmosphere and the functional and planning structure of the city]. Vestnik Voronezhskogo gosudarstvennogo universiteta. Seria: Geografia. Geoekologia, 2014, no. 4, pp. 57-67. (in Russ.)

2. Galkin A. N., Timoshkova A. D., Krasovskaya I.A., Torbenko A.B. Osobennosti proyavleniya sovremennykh ekzogennykh protsessov na territorii Vitebska [Features of the manifestation of modern exogenous processes on the territory of Vitebsk]. Lítasfera, 2007, no. 1 (26), pp. 73-77. (in Russ.)

3. Nesmelova E. I., Filippova M. G. Mikroklimatologiya [Microclimatology]. Moscow: Geographical Faculty Moscow State University Publ., 2006. 186 p. (in Russ.)

4. Isakov S.V. Ispol'zovaniye geoinformatsionnykh sistem dlya kompleksnoy otsenki mikroklimaticheskikh osobennostey territorii [The use of geographic information systems for a comprehensive assessment of the microclimatic features of the territory]. Meteospektr, 2013, pp. 80-85. (in Russ.)

Торбенко Андрей Борисович

старший преподаватель кафедры экологии и географии, Витебский государственный университет им. П.М. Машерова, г. Витебск, Республика Беларусь, ORCID: 00000003-2633-6285, e-mail: torbenko_a@mail.ru

Галкин Александр Николаевич

доктор геолого-минералогических наук, профессор кафедры экологии и географии, Витебский государственный университет им. П.М. Машерова, г. Витебск, Республика Беларусь, ORCID: 0000-0002-1667-2026, e-mail: galkin-alexandr@yandex.ru

Новиков Дмитрий Владимирович

младший научный сотрудник НИС, Витебский государственный университет им. П.М. Машерова, г. Витебск, Республика Беларусь, ORCID: 0000-0002-12449425, e-mail: novikau.d@mail.ru

Ирина Николаевна Иванова-Логвинова

начальник лаборатории экологического мониторинга филиала "Витебский областной центр по гидрометеорологии и мониторингу окружающей среды" ГУ "Республиканский центр по гидрометеорологии, контролю радиоактивного загрязнения и мониторингу окружающей среды", г. Витебск, Республика Беларусь, ORCID: 00000002-7875-5476, e-mail: Lem.vitebsk.2017@mail.ru
5. Romanova E.N., Gobarova E. O., Zhiltsova E.L. Metody ispol'zovaniya sistematizirovannoy klimaticheskoy i mikroklimaticheskoy informatsii pri razvitii i sovershenstvovanii gradostroitel'nykh kontseptsiy [Methods of using systematized climatic and microclimatic information in the development and improvement of urban planning concepts]. Saint Petersburg: Gidrometeoizdat Publ., 2000. 160 p. (in Russ.)

6. Romanova E.N., Gobarova E.O., Zhiltsova E.L. Metody mezo- i mikroklimaticheskogo rayonirovaniya dlya tseley optimizatsii razmeshcheniya sel'skokhozyaystvennykh kul'tur s primeneniyem tekhnologii avtomatizirovannogo rascheta [Methods of meso- and microclimatic zoning for the purpose of optimizing the placement of agricultural crops using automated calculation technology]. Saint Petersburg: Gidrometeoizdat Publ., 2003. 104 p. (in Russ.)

Conflict of interests: The authors declare no information of obvious and potential conflicts of interest related to the publication of this article.

Received: 26.11.2020 Accepted: 03.09.2021

Andrey B. Torbenko

Senior Lecturer of the Department of Ecology and Geography, Vitebsk State University named after P.M. Masherov, Vitebsk, Republic of Belarus, ORCID: 0000-0003-26336285, e-mail: torbenko_a@mail.ru

Aleksandr N. Galkin

Dr. Sci. (Geol.-Min.), Professor of the Department of Ecology and Geography, Vitebsk State University named after P.M. Masherov, Vitebsk, Republic of Belarus, ORCID: 0000-0002-1667-2026, e-mail: galkin-alexandr@yandex.ru

Dmitry V. Novikov

Junior Researcher in the RS, Vitebsk State University named after P.M. Masherov, Vitebsk, Republic of Belarus, ORCID: 0000-0002-1244-9425, e-mail: novikau.d@ mail.ru

Irina N. Ivanova-Logvinova

Head of the environmental monitoring laboratory of the branch "Vitebsk regional centre for hydrometeorology and environmental monitoring" of the State Institution "Republican centre for hydrometeorology, control of radioactive pollution and environmental monitoring", Vitebsk, Republic of Belarus, ORCID: 0000-0002-78755476, e-mail: Lem.vitebsk.2017@mail.ru 